\title{
Torsión de la anastomosis ileorrectal posterior a una colectomía total por vía laparoscópica*
}

\author{
Drs. GINO CASELLI M. ${ }^{1}$, CECILIA BESA C. ${ }^{2}$, GEORGE PINEDO M. ${ }^{1}$
}

1 Departamento de Cirugía Digestiva.

2 Departamento de Radiología.

Pontificia Universidad Católica de Chile, Santiago, Chile.

\section{Torsion of ileorectal anastomosis}

Paciente sometida a una colectomía total e ileorrectoanastomosis laparoscópica (CT + IRA) por inercia colónica (IC) que ingresó por dolor abdominal, distensión y ausencia de eliminación de gases. La tomografía computada (TC) informó obstrucción intestinal (OI) de alto grado y una probable estenosis anastomótica. La colonoscopia mostró hallazgos sugerentes de una estenosis de IRA, realizando dilatación neumática, pero con posterior persistencia de sintomatología. Una nueva TC mostró acentuada dilatación de asas con cambio abrupto de calibre y torsión del mesenterio proximal a la IRA (Figura1). Durante la laparotomía exploradora se identificó malrotación en sentido horario del íleon por sobre el eje del recto distal en el contexto de una IRA lateroterminal previa (Figura 2). Se realizó una resección del segmento y confección de una nueva IRA.

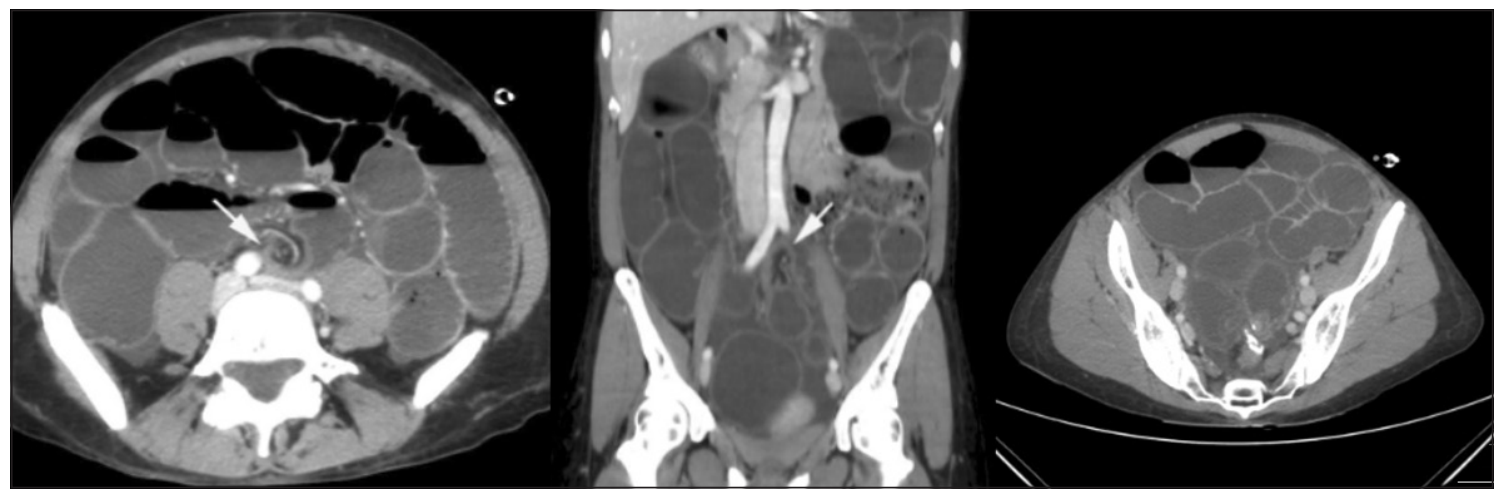

Figura 1. Imágenes axiales (a) y coronal (b) de TC demuestran signos de obstrucción intestinal con acentuada dilatación de asas de intestino delgado y un sitio de transición abrupto a aproximadamente $20 \mathrm{~cm}$ de la IRA, donde se observa torsión de los vasos del mesenterio (flechas), hallazgos compatibles con una torsión de la anastomosis IRA. (c) Imagen axial mostrando cambios post-quirúrgicos de la IRA.

*Recibido el 12 de mayo de 2011 y aceptado para publicación el 15 de junio de 2011.

Correspondencia: Dr. Gino Caselli M.

Marcoleta 350. Patio interior, Santiago, Chile.

gcaselli@uc.cl 


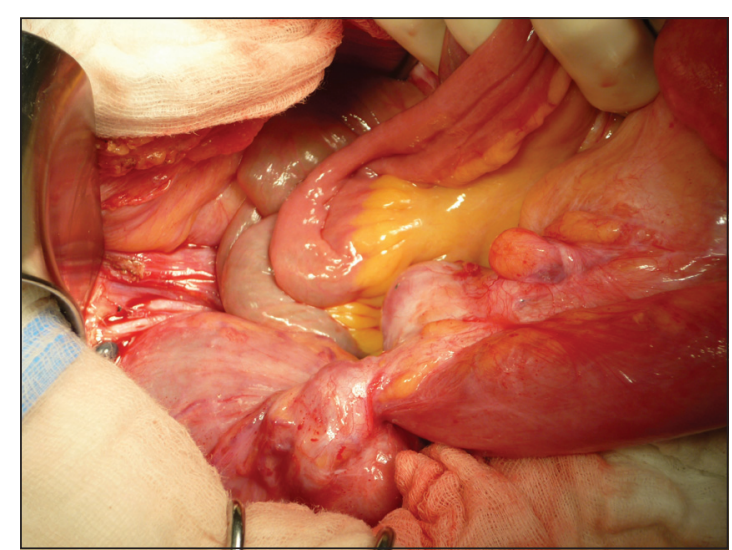

Figura 2: Hallazgos intraoperatorios con evidencias de torsión de la IRA en sentido horario.

La CT + IRA como tratamiento de la IC ha sido parcialmente resistida debido a sus complicaciones postoperatorias ${ }^{1,2}$. Diversas series muestran tasas de obstrucción desde $2 \%$ a $70 \%$, relacionadas con adherencias y motilidad anormal en grupos con trastornos funcionales, sin reportes de torsión de la IRA como causa obstructiva. Si bien la laparoscopia ha disminuido las tasas de OI, que llegan a $20 \%$ en series abiertas ${ }^{3}$, existen medidas para disminuir la posibilidad de torsión, como la disección cercana al intestino grueso con mayor remanente de mesocolon, fijación al peritoneo parietal y la confección terminoterminal de la IRA. Creemos que la dilatación del asa ciega en IRA lateroterminales se asocian a sobrecrecimiento bacteriano que pudiera ser factor predisponente de torsión de la IRA.

\section{Referencias}

1. Elton C, Makin G, Hitos K, Cohen C. Mortality, morbidity and functional outcome after ileorectal anastomosis. Br J Surg. 2003;90:59-65.

2. Gutt C, Oniu T, Schemmer P, Mehrabi A, Buchler M. Fewer adhesions induced by laparoscopic surgery. Surg Endosc. 2004;18:898-906.

3. Pikarsky A, Singh J, Weiss E, Nogueras J, Wexner S. Long-term follow-up of patients undergoing colectomy for colonic inertia. Dis Colon Rectum 2001;44:179-83. 